\title{
Teacher Knowledge in Early Childhood Gender Education
}

\author{
Roudlotul Islamiyah ${ }^{1}$ \\ Universitas Negeri Yogyakarta \\ Suparno ${ }^{2}$ \\ Universitas Negeri Yogyakarta
}

DOI: https://doi.org/10.21009/JPUD.132.09

Accepted: August 15 2019 . Approved: September $4^{\text {th }}$ 2019. Published: $30^{\text {th }}$ November 2019

\begin{abstract}
The industrial development era 4.0, many threats lurk children in the form of bad influence through books, videos, or other media and become a challenge for parents and teachers. Gender education and the introduction of personal identity are important given early on. This study aims to determine the effect of teacher knowledge on the implementation of gender education in early childhood. This research uses quantitative survey research methods with a simple linear regression design for data analysis. The respondents were 34 early childhood education teachers. The results show the data with the conclusion that the calculated value $>t$ table and $p$-value (sig) of 0.001 $(<0.05)$ which means that there is a significant influence on teacher knowledge about early childhood gender education. Research suggests about how to improve gender education in early childhood education and create learning modules for early childhood teacher guidance.
\end{abstract}

Keywords: Early gender education, Teacher knowledge about gender education

\footnotetext{
(C) 2019 Early Childhood Education Post Graduate Program UNJ, Jakarta e-ISSN (Online Media): 2503-0566

P-ISSN (Print Media): 1693-1602
}

\footnotetext{
${ }^{1}$ Corresponding Author;

Email: roudlotulislamiyah84@gmail.com
} 


\section{INTRODUCTION}

Early childhood education can be a space to provide 'gender flexible pedagogy', a concept that combines ideas about staff modeling of alternative forms of masculinity and femininity, the value of mixed gender labor, and explicit gender teaching in the curriculum. Warin \& Adriany, (2017)'s findings indicate that gender practices in ECE are rooted in the implicit gender beliefs of teachers who are influenced by greater socio-political discourse. Early childhood educators must develop explicit gender awareness before they can provide gender conscious pedagogy.

Lynch, (2015) shows that these teachers strengthen gender attitudes by encouraging children, especially boys, to play only with toys and in activities traditionally linked to their gender and suggest that further research examine gender games in kindergarten, and that kindergarten teachers can benefit from awareness of their unintentional teachings and in learning how it is better to encourage gender equality in play-based classroom activities.

Gender is a complex field, with various opinions on how gender is formed in individuals and their role in society. this study that the gender perception of early childhood educators does indeed influence children's play. The social and individual environment in it is important for children's development and understanding of gender roles. According to Chapman, (2016), it is important to design children's schedules and activities as well as how teachers facilitate and support children's participation.

Early childhood or preschool education teachers still have limited knowledge and experience about gender education (Muasya \& Kazungu, 2018). The limited experience of educators in recognizing gender patterns and the accuracy of their attitudes and beliefs is one of the keys to why gender education has not been optimal so that it influences interaction with children (Filipović, 2018). Based on the background of these problems, it is very necessary for gender education for children. The teacher as someone who is trusted in educating children in schools is also obliged to provide and implement gender education that is appropriate for children with good knowledge about gender education. This study aims to look at the effect of teacher knowledge on the implementation of gender education in early childhood.

\section{THEORITICAL STUDY}

\subsection{Teacher Knowledge about Early Childhood Gender Education}

Educators have full responsibility in developing the abilities of their students or students with a neutral attitude without differentiating gender, religion, ethnicity, social class so that they are able to assist children in understanding relationships with friends or others (Fortunato \& Iorio Dias, 2018). Early childhood teacher education becomes an obligation in conducting the same or similar care as the care done by their parents (Wu et al., 2015).

The wealth of teacher knowledge and skills possessed by early childhood teachers with higher education will have a very positive and effective influence on the future development of children (La Paro, Van Schagen, King, \& Lippard, 2018). The teacher's knowledge framework includes three ways namely by "knowing why", "knowing how", and "knowing what" that aims to find out and incorporate in an effort to build deep understanding so that teacher knowledge can be optimal (Adoniou, 2015). Based on existing theories, teacher knowledge is the result of sensing obtained from the experience of teachers as educator who must provide and have the knowledge to be able to provide appropriate education for children. 
Gender can cause children to obtain different social expectations and attitudes to learning for both sexes. The dimorphic treatment often done by boys and girls is often based on the assumption of biological differences. This can result in approaches to the care and education of children that are assigned to their gender categories rather than their individual needs. Wingrave, (2018) findings indicate that there is a belief among groups of educators that gender is innate or learned and that teachers do not play a role in gender education in children. This needs to be straightened out and training for teachers related to gender education in early childhood is needed.

\subsection{Early Childhood Gender Education}

The Gender Equality Law applies to women and men, and it is seen as an instrument to improve the situation of women in particular. Gender stereotypical perceptions in kindergartens and schools contribute to limiting the freedom of children to make their own educational choices according to their interests and strengths (Meland \& Kaltvedt, 2019). Early childhood education has a goal that is to provide stimulus as an encouragement to develop all the potential of children who have faith and believe in God, knowledgeable, healthy, critical, capable, independent, and innovative (Suyadi, 2014).

Huggins, (2014) was able to show changes in children's behavior for 2 years by observing activities that the children themselves defined as toys that suited girls or boys and learned to adapt to them. The choice of activities and behaviors is done to match the expectations of other children. Data shows boys often play battles and superhero games and girls play scenarios around home life and fairy tales. The research also notes how young children are involved in heterosexual games, such as boyfriend / girlfriend scenarios, with children who carry out their gender identity and use fantasy to position and position themselves as they try various ways to be boys and become girls.

The preference of toys to be very gender, with toys and boys' resources concentrated on technology and action, and girls on caring and feminine stereotyping interests. All toys and resources are involved in 'gender': various gender discourses, and other discourses around aspects of social identity that are reflected in toys. It is important to pay close attention to children's toys in gender roles and the production of social identity (Francis, 2010). Intergroup developmental theory predicts that children develop fewer or weaker stereotypes about toys that have gender attributes. Color is the reason most often used for gender assignment of toys. Cherney \& Dempsey, (2010) highlights the role of perception salience in the preferences and behavior of toy selection and its application to educational problems.

Gender type is the implementation of gender roles, starting from early childhood, but it will vary greatly at the level in which they become gender type. Gender stereotyping is a generalization of prejudices about male or female behavior through an understanding that all women are dependent and passive, while all men are independent and active, which begin to emerge at the age of children 2-3 years and will peak at the age of 5 years (Papalia \& Duskin, 2015). One theory says that gender education is the process of finding the nature of life until a person has a better understanding his gender identity, both their role in society and gender stereotypes, so that there is no issue about gender-confusion.

Gender education is not only the obligation of teachers but also the overall needs of schools so that they are able to provide gender space to develop the potential of children who are adapted to their gender (Frödén, 2019). Gender education becomes a place in developing personalities that 
might exchange roles so that it will be easier in a career in the next child's life (Zhukovskyi \& Kostiuk, 2015). Gender education is very important to be implemented well in schools because all threats can occur anywhere. The following is a way to maintain personal safety related to the gender education in schools, which are as follows: to avoid all forms of violence both sexual, physical, emotional, and psychological, gender equality must be prioritized in academic and nonacademic or extra-curricular activities, and against there is discrimination against gender both men and women (Vanner, 2019). Gender education in children aims to be more empathetic to other people who have the same or different gender, respect each other, be active in social activities, have critical thinking skills (Zhukovskyi \& Kostiuk, 2015). The importance of gender education in children should motivate teachers and parents to be able to implement appropriate gender education to the children with sufficient knowledge.

\section{METHODS}

\subsection{Participant}

This study used a quantitative research method with survey research type because This study was used to determine the relationship and influence of the two variables with the source of the data obtained from the questionnaire. This study used a sample of 34 teachers aged 22-45 years in a cluster in Surabaya with educational backgrounds ranging from high school to master's degree. All respondents stated that they have known, and applied gender education sourced from their experiences, books, internet and others.

The results of filling out the questionnaire by respondents obtained 34 data, sourced from Early Childhood Education Teachers (PAUD) in a cluster in Surabaya that was chosen by a random system. These teachers aged around 22 to 45 years with a teaching experience of 1 to 7 years and all were female. Based on the results of the questionnaire in the private column, all of the respondents have known and implemented gender education in the learning process at school. As many as 20 teachers understand gender material from experiences either based on their personal experiences or others' experiences, while the rest understand the material from books, television and the internet. Teachers' understanding of gender education from various sources will be the basis in determining the extent to which gender education material is known by the teacher and the extent of its application to children.

Table 1. Respondent Data

\begin{tabular}{lll}
\hline No & Respondent Data & Number of Respondents \\
\hline 1 & Age & \\
\cline { 2 - 3 } & 22 & 2 \\
\cline { 2 - 3 } & 23 & 3 \\
\cline { 2 - 3 } & 24 & 4 \\
\cline { 2 - 3 } & 25 & 13 \\
\cline { 2 - 3 } & 26 & 6 \\
\cline { 2 - 3 } & 27 & 2 \\
\cline { 2 - 3 } & 28 & 1 \\
\hline & 36 & 1 \\
\hline & 37 & 1 \\
\cline { 2 - 3 } & Amount & 1 \\
\hline 3 & Sex & 34 \\
\cline { 2 - 3 } & Man & \\
\cline { 2 - 3 } & Woman & 34 \\
\hline
\end{tabular}




\begin{tabular}{lll}
\hline & Amount & 34 \\
\hline 4 & Last education & \\
\cline { 2 - 3 } & SMA & 2 \\
\cline { 2 - 2 } & Diploma & 1 \\
\cline { 2 - 2 } & Bachelor (S1) & 30 \\
\cline { 2 - 3 } & Master(S2) & 1 \\
\cline { 2 - 3 } & Amount & 34 \\
\hline 5 & Sources of Information About Gender Education \\
\cline { 2 - 3 } & 5 Sources & 2 \\
\cline { 2 - 3 } & 4Sources & 3 \\
\cline { 2 - 3 } & 3 Sources & 2 \\
\cline { 2 - 3 } & 2 Sources & 7 \\
\cline { 2 - 3 } & 1 Sources & 20 \\
\cline { 2 - 3 } & Amount & 34 \\
\hline
\end{tabular}

\subsection{Instrument}

This study used 12 items in the same instrument, but only the variable of teacher's knowledge was more emphasized on the question of whether teachers know about gender education material for their students. The application variable was accentuated on existing gender education material, such as whether gender education has been carried out or how often gender education has been applied to children. The teacher will fill the questionnaire with questions that state knowledgeyes by choosing answers from not knowing, doubting, knowing, and knowing very well while in practice, the teacher can answer from the existing questionnaire by choosing one of the never, sometimes often and always.

The items in the instrument were made into a questionnaire filled out by the respondents by selecting one of the choices based on the knowledge they have and the application of gender education to the children they have done. Data analysis in this study used simple linear regression analysis which was calculated using SPSS 21 . Normality and homogeneity tests were also performed as additional requirements because in analyzing data using simple linear regression the data must be normal and homogeneous. Normality test was used to minimize errors, whereas homogeneity of variance test was needed to ensure that differences were not caused by the differences in database.

Table 2. Gender Education Research Instruments

\begin{tabular}{|c|c|c|}
\hline No. & Aspects & Sub Aspects \\
\hline \multirow[t]{4}{*}{1} & \multirow{4}{*}{$\begin{array}{l}\text { Gender roles in the environment (the } \\
\text { desire, skills, behaviors, and atti- } \\
\text { tudes) }\end{array}$} & 1. The desires that are compatible with gender \\
\hline & & 2. The attitudes of masculinity and femininity \\
\hline & & 3. Hobby or desires according to gender \\
\hline & & 4. The behavior that is gender-specific \\
\hline \multirow[t]{3}{*}{2} & \multirow[t]{3}{*}{ Gender stereotypes } & 5. Work according to gender \\
\hline & & 6. The choices of games or toys according to gender \\
\hline & & 7. Idol who is admired corresponding to gender \\
\hline \multirow[t]{3}{*}{3} & \multirow[t]{3}{*}{ Stages of the development of gender } & 8. Stability (no changes) \\
\hline & & $\begin{array}{l}\text { 9. Consistency (attributes used will not alter the gen- } \\
\text { der }\end{array}$ \\
\hline & & 10. Gender identity (understanding about gender) \\
\hline
\end{tabular}




\begin{tabular}{lll}
4 & Factors that influence & 11. Biological \\
\cline { 2 - 2 } & gender development & 12. Social
\end{tabular}

\subsection{Data Validity}

The existing instrument must be validated to the expert (lecturer) for validation related to the content. The results of the instrument validation were then tested on 12 teachers in Surabaya who had an age between $22-45$ years. The following are the results of validity in this study:

Table 3. The Validity of Teacher Knowledge

\begin{tabular}{lll}
\hline Validity & Corrected item-total correlation & \\
\hline Item1 & $.915^{* *}$ & Valid \\
\hline Item2 & $.843^{* *}$ & Valid \\
\hline Item3 & $.622^{*}$ & Valid \\
\hline Item4 & $.747^{* *}$ & Valid \\
\hline Item5 & $.754^{* *}$ & Valid \\
\hline Item6 & $.740^{* *}$ & Valid \\
\hline Item7 & $.890^{* *}$ & Valid \\
\hline Item8 & .574 & Valid \\
\hline Item9 & $.804^{* *}$ & Valid \\
\hline Item10 & $.747^{* *}$ & Valid \\
\hline Item11 & $.890^{* *}$ & Valid \\
\hline Item12 & $.924^{* *}$ & Valid \\
\hline Total & 1 & \\
\hline
\end{tabular}

Based on the results of the validity calculation it is known that the $\mathrm{r}$ count for all items is greater than 0.3 so that it can be stated that the teacher's instrument knowledge of the variable is declared valid.

Table 4. Validity of The Opplication of Gender Education

\begin{tabular}{ccc}
\hline Validity & Corrected item-total correlation & \\
\hline Item1 & $.880^{* *}$ & Valid \\
\hline Item2 & .569 & Valid \\
\hline Item3 & .500 & Valid \\
\hline Item4 & $.880^{* *}$ & Valid \\
\hline Item5 & .458 & Valid \\
\hline Item6 & $.722^{* *}$ & Valid \\
\hline Item7 & $.601^{*}$ & Valid \\
\hline Item8 & $.751^{* *}$ & Valid \\
\hline Item9 & $.880^{* *}$ & Valid \\
\hline Item10 & $.726^{* *}$ & Valid \\
\hline Item11 & $.591^{*}$ & Valid \\
\hline Item12 & $.690^{*}$ & Valid \\
\hline
\end{tabular}


Based on the results of the validity calculation it is known that the $r$ count for all items is greater than 0.3 so that it can be stated that the teacher's instrument knowledge of the variable is declared valid.

\subsection{Reliability}

Following this the reliability was carried out for 12 teachers in Surabaya who had ages between 22 and 45 years. The following reliability results in this study:

Table 5. Reliability Statistics Teacher Khowledge

\begin{tabular}{rr}
\hline Cronbach's Alpha & \multicolumn{1}{c}{ N of Items } \\
\hline .941 & 12 \\
\hline
\end{tabular}

Based on the results of the reliability calculation, it is known that the Cronbach's Alpha value is greater than 0.6 , which is 0.941 so it can be stated that the teacher's variable knowledge variables are reliable.

Table 6. Reliability Statistics the Application of Gender Education

\begin{tabular}{rr}
\hline Cronbach's Alpha & \multicolumn{1}{c}{ N of Items } \\
\hline .894 & 12 \\
\hline
\end{tabular}

Based on the results of the reliability calculation, it is known that the Cronbach's Alpha value is greater than 0.6 , which is 0.894 so it can be stated that the teacher's variable knowledge variables are reliable.

The hypotheses in this study are as follows:

Ha: there is a significant influence on teachers' knowledge about early childhood gender education.

Ho: There is no significant effect on teacher knowledge about gender education in early childhood.

\section{RESULT AND DISCUSSION}

\subsection{Results}

The collected data then were examined the requirement tests which were normality and homogeneity test using SPSS 21 to determine the data were normally distributed and homogeneous. The result of the normality test can be seen from the following table:

Table 7. Tests of Normality

\begin{tabular}{llccccccc}
\hline & \multirow{2}{*}{ Gender Education } & \multicolumn{3}{c}{ Kolmogorov-Smirnova $^{\text {a }}$} & \multicolumn{4}{c}{ Shapiro-Wilk } \\
\cline { 2 - 10 } & Statistic & df & Sig. & Statistic & df & \multicolumn{1}{l}{ Sig. } \\
\hline \multirow{2}{*}{ Skor } & Knowledge & .193 & 34 & .103 & .921 & 34 & .067 \\
\cline { 2 - 9 } & Application & .098 & 34 & $.200^{*}$ & .959 & 34 & .228 \\
\hline
\end{tabular}

*. This is a lower bound of the true significance.

a. Lilliefors Significance Correction 
Based on the normality test results table, it can be concluded that the probability or significance level in the column kolmogorov-smirnov and shapiro-wilk is more than $<0.05$ so it shows that the data obtained in this study are normal and normality tests have been met.

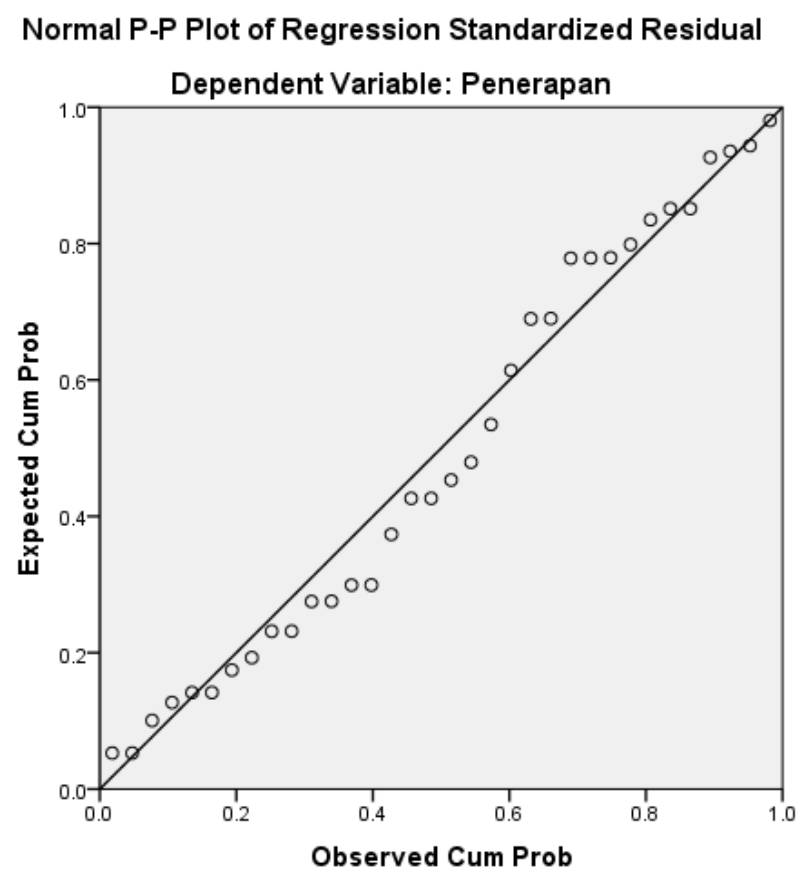

Figure 1. Plot of normality

In addition, the normality test can be seen from the normality plot. Guidelines for making decisions on the normality test using a plot that is by looking at the existing points, if the points are close to the line then declared normal distribution and vice versa if the points away from the line means the data is not normal (Ghozali, 2011). The homogeneity test is used to see whether the data is homogeneous or not.

Table 8 . Test of homogeneity of variance

\begin{tabular}{llcccc}
\hline & & $\begin{array}{c}\text { Levene } \\
\text { Statistic }\end{array}$ & DF1 & DF2 & Sig. \\
\hline \multirow{3}{*}{ Score } & 1.003 & 1 & 66 & .320 \\
\cline { 2 - 6 } & $\begin{array}{l}\text { Based on Mean } \\
\text { Based on Median }\end{array}$ & .326 & 1 & 66 & .570 \\
\cline { 2 - 6 } & $\begin{array}{l}\text { Based on the median and } \\
\text { with adjusted df }\end{array}$ & .326 & 1 & 58.551 & .570 \\
\cline { 2 - 6 } & Based on the trimmed mean & .903 & 1 & 66 & .346 \\
\hline
\end{tabular}

Based on the result table of the test of homogeneity of variance, it can be concluded that the probability value or significance level based on mean above 0.05 indicates that the data obtained in this study are homogeneous and homogeneity tests have been fulfilled. After obtaining the results of normality and homogeneity tests that have stated fulfilling the requirements, then the data were analyzed using SPSS 21 with a simple linear regression analysis.

The results of a simple linear regression analysis using SPSS 21 are presented in table 3 in the descriptive statistics. 
Table 9. Descriptive Statistics

\begin{tabular}{llll}
\hline & Mean & Std. deviation & $\mathbf{N}$ \\
\hline Implementation (y) & 32.79 & 8731 & 34 \\
\hline Knowledge (x) & 32.85 & 9835 & 34 \\
\hline
\end{tabular}

The descriptive statistics table explains that the knowledge variable $(\mathrm{x})$ which becomes the independent variable has an average of 32.79 with a standard deviation of 8.73 and the application variable (y) which becomes the dependent variable has an average of 32.85 with the standard 9.84 deviation.

Table 10. Correlations

\begin{tabular}{llll}
\hline & & Application & \multicolumn{1}{c}{ Knowledge } \\
\hline \multirow{2}{*}{ Pearson Correlation } & Application & 1,000 & .562 \\
\cline { 2 - 4 } & Knowledge & .562 & 1,000 \\
\hline \multirow{2}{*}{ Sig. (One-tailed) } & Application & \multicolumn{2}{c}{.000} \\
\cline { 2 - 4 } & Knowledge & .000 & \multicolumn{1}{c}{} \\
\hline \multirow{2}{*}{$\mathrm{N}$} & Application & 34 & 34 \\
\cline { 2 - 4 } & Knowledge & 34 & 34 \\
\hline
\end{tabular}

The correlation between knowledge and application variables can be seen in table 4 . As stated on the table, the significance of the knowledge variable $(\mathrm{x})$ with the implementation variable (y) gets a result of 0,000 which means less than 0.05 . It can be concluded that the teacher's knowledge has significant correlation with the application of gender education in early childhood.

Table 11. Summary

\begin{tabular}{|c|c|c|c|c|c|c|c|c|c|c|}
\hline \multirow[t]{2}{*}{ Model } & \multirow[t]{2}{*}{$\mathbf{R}$} & \multirow{2}{*}{$\begin{array}{l}\text { R } \\
\text { Square }\end{array}$} & \multirow{2}{*}{$\begin{array}{l}\text { Ad- } \\
\text { justed R } \\
\text { Square }\end{array}$} & \multirow{2}{*}{$\begin{array}{l}\text { Std. } \\
\text { Error } \\
\text { of the } \\
\text { Esti- } \\
\text { mate }\end{array}$} & \multicolumn{3}{|c|}{ Change Statistics } & & & \multirow{2}{*}{$\begin{array}{l}\text { Durbin- } \\
- \text { Watson }\end{array}$} \\
\hline & & & & & $\begin{array}{l}\mathbf{R} \\
\text { Square } \\
\text { Change }\end{array}$ & $\begin{array}{l}\text { F } \\
\text { Change }\end{array}$ & $\begin{array}{l}\text { DF } \\
1\end{array}$ & $\begin{array}{l}\text { DF } \\
2\end{array}$ & $\begin{array}{l}\text { Sig. F } \\
\text { Change }\end{array}$ & \\
\hline 1 & $.562 \mathrm{a}$ & .316 & .295 & 7.331 & .316 & 14811 & 1 & 32 & .001 & 1,539 \\
\hline
\end{tabular}

The summary table presented can clarify the extent of the correlation between the two variables, namely the variable of knowledge and application. The level of correlation (R) between the two variables obtained a strong result that is 0.562 or $56.2 \%$. Adjusted R square ( $\mathrm{r} 2$ ) is a coefficient that showed a result of 0.316 , which means that the teacher's knowledge as a variable $\mathrm{x}$ contributed $31.6 \%$ to the variable $y$, while the remaining $68.4 \%(100 \%-31.6 \%)$ was influenced by other factors. Std. Error of the estimate obtained a result of 7,331 which reflected the standard error of the assessment. The smaller of the standard error is produced, compared to the standard deviation of the dependent variable (dependent / y), the more appropriate the regression model is in predicting the dependent variable $(\mathrm{y})(7,331<8,731)$.

Table 12. ANOVA ${ }^{\mathrm{a}}$

\begin{tabular}{llclccc}
\hline \multicolumn{2}{l}{ Model } & Sum of Squares & Df & Mean Square & F & Sig. \\
\hline 1 & Regression & 795906 & 1 & 795906 & 14811 & $.001^{\mathrm{b}}$ \\
\hline
\end{tabular}




\begin{tabular}{llll}
\hline Residual & 1719.653 & 32 & 53739 \\
\hline Total & 2515.559 & 33 & \\
\hline
\end{tabular}

From the ANOVA test, the result of the F ratio test was 14.811 and the p value (sig) was 0.001 $(<0.05)$, which means the regression model can be used to predict the application of gender education for early childhood.

Table 13. Coefficients

\begin{tabular}{lllllll}
\hline Model & \multicolumn{2}{l}{$\begin{array}{l}\text { Coefficients Unstand- } \\
\text { ardized }\end{array}$} & $\begin{array}{c}\text { Standardized } \\
\text { Coefficients }\end{array}$ & T & Sig. \\
\cline { 2 - 5 } & $\mathbf{B}$ & Std. Error & beta & & \\
\hline \multirow{2}{*}{1} & 16390 & 4,444 & & 3.688 & .001 \\
\cline { 2 - 5 } Knowledge & .499 & .130 & .562 & 3,848 & .001 \\
\hline
\end{tabular}

The coefficients table explains that there was one independent variable (x) included in the regression model. The parental knowledge variable has a statistical $t$-value $\left(t_{\text {count }}\right)$ of 3.848 and $t_{\text {table }} 32$ was $1.69389(\mathrm{~N}=34-2$ (degrees of freedom $)=32)$, so $t_{\text {count }}>t_{\text {table }}$ and $p$-value (sig.) equal to 0.001 $(<0.05)$ which means that teacher knowledge has a significant influence on the application of gender education to early childhood. Here is the result of the regression equation obtained.

$$
y=16,390+0,499 x
$$

Beta coefficient of 0427 states that each additional 1 value on the application of gender education will increase of the value of the suitability 0,427 educational materials gender in the media, if the value of $x=1$ then $\hat{y}=34$.

$$
\mathrm{y}=16,390+0,499(1)
$$

\subsection{Discussion}

This study aims to determine the effect of teacher knowledge about the implementation of gender education in early childhood by using questionnaires that have been filled by 34 teachers. The results of this study are expected to be able to provide views to teachers and the community about the relationship or influence of gender education knowledge on the application of gender education to early childhood.

Gender education is an undoubtedly pivotal matter when the concept of gender which is naturally owned by human being conflicts with their sexes. LGBT (Lesbian, Gay, Bisexual, and Transgender) is an issue that needs more attention nowadays in which this phenomenon can make early childhood children as a target that can be recruited into LGBT people. This should be a precaution for teachers as educators who share responsibility for the survival of the nation through its successor generation. The formation of a person's attitude can be influenced by others such as family, teachers, peers and the community, as expected or in the opinion of others including in the education process (Azwar, 2010). The teacher becomes the most ideal space in giving a straight view related to gender education to children beside parents' obligation.

Education is a process of changing behavior and attitudes of a child in an effort to mature humans through the process of training, educating, and teaching (Nursalam, 2014). Educational process is expected to be able to provide an understanding of gender education that is appropriate for early childhood in accordance with the direction of the teacher as a source of teaching for children. The 
process of providing and applying gender education is unlikely to run well when teachers do not have the proper understanding and knowledge to provide to early childhood.

The teachers who became respondents were aged 22 to 45 years. Age is very important in measuring parental knowledge and the extent of the application of gender education to early childhood. A person's age greatly influences the maturity of thinking and ability to capture information well so that it can increase one's knowledge (Awaji M, 2016). Maturity intervenes in a person's ability to obtain more diverse information and gives awareness in the importance of having the knowledge to prepare to implement good education for children including gender education.

Educational background of respondents ranging from high school to master's degree also greatly influences the process of implementing gender education for early childhood. Level of education has an influence in obtaining information, the higher a person's education, the more information will be obtained so that it is likely that the knowledge obtained will be more adequate (Solehudin, 2018). Parent or teacher mindset can be seen from the higher education they have because the higher the teacher's education will further complement and expand the mindset in educating children (Sulastri \& Ahmad Tarmizi, 2017). The minimum requirement to become PAUD teachers in Indonesia is bachelor graduate so that they are expected to have good knowledge and be able to apply education, including appropriate gender education.

Correlation between two variables which showed a result of 0.316 figures the teacher's knowledge as a means to Contribute $31.6 \%$ of the variable $\mathrm{x}$ to the variable $\mathrm{y}$ is the application of gender education, while the remaining $68.4 \%$ (100\%-31.6\%) influenced by other factors. Relationship or correlation between teachers' knowledge and application of the calculation analysis of gender education was 0,000 roommates is less than $0: 05$, it can be concluded that the knowledge teachers have a significant relationship with the implementation of gender education in early childhood.

The correlation between education teacher knowledge with the application of a significant gender Showed $31.6 \%$ of teachers Affect the application of knowledge of gender education and the remaining $68.4 \%$ influenced by other factors oleg and will affect a person's behavior. The behavior will form more lasting or last a long time if it is based on good knowledge so that they can apply the information obtained based on the knowledge they have (Notoatmodjo, 2014).

The result of simple linear regression analysis was $t_{\text {count }}>t_{\text {table }}$ and p-value (sig.) of $0.001(<0.05)$ which means that teacher knowledge has an influence on the application of gender education in early childhood because the observation hypothesis (Ho) was rejected and the alternative hypothesis (Ha) was not rejected (accepted) so it can be concluded that there is a significant influence of teacher knowledge on the application of gender education in early childhood.

The results of these conclusions are in line with the theories of Salawati et al. which states that the application occurs through a process of practice that is influenced by internal factors derived from one's own experience and external factors that are influenced by the knowledge of other (Salawati, Herry, \& Putra, 2014). The application of gender education which is influenced by the teacher's knowledge makes the learning process in line with the educational objectives, namely, to educate the nation's children as the next generation who must be protected from all forms of threats and doubts in their gender.

Gender education for early childhood will be able to make children easily accept the existence of his body as a whole and accept the developmental phases in a reasonable manner, help children know biological topics such as growth, puberty, and pregnancy, and the child's gender role will 
understand and feel satisfied with their roles in society according to their sex or help young people ask questions about the roles of men and women in the community with the help of parents and teachers.

Once the importance of gender education in children makes giving gender education to children must also be very considered. The teacher as a source of information for children should have good knowledge about gender education and how to apply it to children. Very influential knowledge with absorption makes these two things must be in harmony and in line so that children have a good provision of gender education from teachers who have the knowledge and are able to apply it.

\section{CONCLUSION}

\subsection{Conclusion}

This study aims to determine the effect of parental knowledge on the application of gender education to early childhood. Teachers become a very influential source of information after parents for children because in addition to parents, teachers must also be able to provide appropriate education for children, one of which is gender education with good knowledge.

The correlation between the knowledge of education teachers and the application of gender is significant. Shows $31.6 \%$ of teachers influence the implementation of gender education and the remaining $68.4 \%$ is influenced by other factors and will influence one's behavior.

The results of simple linear regression analysis based on available data gain the conclusion that $t$ count $>t$ table and p-value (sig.) of $0.001(<0.05)$ means that teacher knowledge has an influence on the application of gender education in early childhood because the observation hypothesis (Ho) was rejected and alternative hypothesis (Ha) was not rejected (accepted) so it can be concluded that there is a significant influence between teacher knowledge and the application of gender education in early childhood.

Significant influence on teacher knowledge about gender education that affects its application to children, makes a reference that teachers must enrich their knowledge in order to be able to apply gender education well to children. The application based on knowledge will last longer so the teacher must have good knowledge in order to be able to apply the right and good gender education to children. The teacher becomes the center in all forms of learning including learning about gender. The success of a child in his life to avoid all threats of bad influences including LGBT will be largely determined by how the teacher or parent provides gender education that is appropriate for the child. Applying appropriate gender education will be able to provide understanding to children to protect themselves from all the bad influences that exist.

\subsection{Suggestion}

Teachers as an educator should always be open to receive information and enrich their knowledge so that all information and knowledge they acquire can be applied appropriately. In addition, through this research, it is hoped that other researchers will be able to develop further this study with different perspectives so that the future of the children will always be well guaranteed through the many studies with various points of view. 


\section{ACKNOWLEDGMENTS}

Lembaga Pengelola Dana Pendidikan (LPDP) Indonesia has provided support in the form of research grants or sponsors or raised funds to complete the study this well.

\section{REFERENCES}

Adoniou, M. (2015). Teacher knowledge: a complex tapestry. Asia-Pacific Journal of Teacher Education, 43(2), 99-116. https://doi.org/10.1080/1359866X.2014.932330

Awaji M, A. K. (2016). Analysis of workrelated injuries among health care workers in armed forces hospi-tal southern region, kingdom of saudi arabia. Br J Med Med Res., 15(4).

Azwar, S. (2010). Sikap Manusia: Teori dan Pengukurannya Edisi 2. Yogyakarta: Pustaka Pelajar.

Chapman, R. (2016). A case study of gendered play in preschools: how early childhood educators' perceptions of gender influence children's play. Early Child Development and Care, 186(8), 1271-1284. https://doi.org/10.1080/03004430.2015.1089435

Cherney, I. D., \& Dempsey, J. (2010). Young children's classification, stereotyping and play behaviour for gender neutral and ambiguous toys. Educational Psychology, 30(6), 651-669. https://doi.org/10.1080/01443410.2010.498416

Filipović, K. (2018). Gender Representation in Children's Books: Case of an Early Childhood Setting. Journal of Research in Childhood Education, 32(3), 310-325. https://doi.org/10.1080/02568543.2018.1464086

Francis, B. (2010). Gender, toys and learning. Oxford Review of Education, 36(3), 325-344. https://doi.org/10.1080/03054981003732278

Frödén, S. (2019). Situated decoding of gender in a Swedish preschool practice. Ethnography and Education, 14(2), 121-135. https://doi.org/10.1080/17457823.2017.1422135

Ghozali, I. (2011). Aplikasi Analisis Mulivariante dengan Program IBM SPSS 19 Edisi 5. Semarang: Badan Penerbit Universitas Diponegoro.

Huggins, V. (2014). Education 3-13 : International Journal of Primary, Elementary and Early Years Education Children at play: Learning gender in the early years. gray2011.p(November). https://doi.org/10.1080/03004279.2011.644316

La Paro, K. M., Van Schagen, A., King, E., \& Lippard, C. (2018). A Systems Perspective on Practicum Experiences in Early Childhood Teacher Education: Focus on Interprofessional Relationships. Early Childhood Education Journal, 46(4), 365-375. https://doi.org/10.1007/s10643-017-0872-8

Lynch, M. (2015). Guys and dolls: a qualitative study of teachers' views of gendered play in kindergarten. Early Child Development and Care, 185(5), 679-693. https://doi.org/10.1080/03004430.2014.950260

Meland, A. T., \& Kaltvedt, E. H. (2019). Tracking gender in kindergarten. Early Child Development and Care, 189(1), 94-103. https://doi.org/10.1080/03004430.2017.1302945

Muasya, J., \& Kazungu, T. (2018). 'The unfinished business': Exploring teachers' views on gender and pedagogical practices in public preschools in Nairobi county, Kenya. African Educational Research Journal, 6(1), 10-19. https://doi.org/10.30918/aerj.61.18.007

Notoatmodjo, S. (2014). Ilmu Perilaku Kesehatan. Jakarta: Rineka Cipta.

Nursalam. (2014). Manajemen Keperawatan: Aplikasi Dalam Praktik Keperawatan Profesional. Jakarta: Salemba Medika. 
Papalia, D. E., \& Duskin, R. (2015). Perkembangan Manusia. Jakarta: Salemba Humanika.

Salawati, L., Herry, N., \& Putra, A. (2014). Analisis Tindakan Keselamatan Dan Kesehatan Kerja Perawat Dalam Pengendalian Infeksi Nosokomial Di Ruang ICU RSUD DR. Zainoel Abidin Banda Aceh. 14(3).

Solehudin, M. (2018). Peran Guru Pai Dalam Mengembangkan Kecerdasan Emosional (EQ) Dan Kecer-dasan Spiritual (SQ) Siswa Smk Komputama Majenang. Jurnal Tawadhu, 1(3).

Sulastri, S., \& Ahmad Tarmizi, A. T. (2017). Peran Orang Tua Dalam Pendidikan Anak Usia Dini. Raudhatul Athfal: Jurnal Pendidikan Islam Anak Usia Dini, 1(1), 61-80. https://doi.org/10.19109/ra.v1i1.1526

Suyadi. (2014). Teori pembelajaran anak usia dini, dalam kajian neourons. Bandung: PT Remaja Rosdakarya.

Vanner, C. (2019). Examining gender safety in schools: Teacher agency and resistance in two primary schools in kirinyaga, kenya. Education Sciences, 9(1). https://doi.org/10.3390/educsci9010063

Warin, J., \& Adriany, V. (2017). Gender flexible pedagogy in early childhood education. Journal of Gender Studies, 26(4), 375-386. https://doi.org/10.1080/09589236.2015.1105738

Wingrave, M. (2018). Perceptions of gender in early years. Gender and Education, 30(5), 587606. https://doi.org/10.1080/09540253.2016.1258457

Wu, Y. P., Wu, J. F., Chen, Y. M., Han, L., Han, P. G., Wang, P., \& Gao, F. (2015). Shyness and School Adjustment Among Chinese Preschool Children: Examining the Moderating Effect of Gender and Teacher-Child Relationship. Early Education and Development, 26(2), 149166. https://doi.org/10.1080/10409289.2015.970503

Zhukovskyi, V., \& Kostiuk, O. (2015). Stages Of Gender Education In Canadian Secondary Schools. Comparative Professional Pedagogy, 5(2), 31-38. https://doi.org/10.1515/rpp2015-0037 